\title{
IKPMDI SEBAGAI WADAH PEMERSATU GAGASAN EMAS PARA MAHASISWA SE- NUSANTARA
}

\author{
Oleh: M. Jamil ${ }^{1}$
}

Ikatan Keluarga Pelajar Mahasiswa Daerah Indonesia (IKPMDI) Yogyakarta yang semula bernama Forum Komunikasi Putra-Putri Indonesia (FUKOPPI) merupakan sebuah konsep organisasi yang berawal dari kegelisahan para mahasiswa-mahasiswa se-Nusantara (beberapa IKPM propinsi), bernotabene kuliah di kota Gudek Yogyakarta. Gagasan tersebut berawal pada tahun 1997. Tahun 1997 merupakan tahun bersejarah bagi IKPMDI-Yogyakarta, karena berawal dari tahun tersebutlah IKPMDI-Yogyakarta masih eksis sampai saat ini.

Tidak bisa dipungkiri, semangat orang dalam berorganisasi terkadang menggumpal ruah, bahkan terkadang mengendor. Terbukti semangat yang mengendor tersebut mengakibatkan FUKOPPI (yang kini jadi IKPMDIYogyakarta) mengalami kefakuman yang cukup lama. Tidak tanggung-tanggung lamanya, sekitar satu periode masa jabatan presiden Republik Indonesia (5 tahun). Dirasa sudah lama terhanyut dalam keasikan tidur yang begitu panjang, tepat tahun 2002, beberapa mantan pengurus FUKOPPI berinisiasi melakukan konsolidasi yang masif guna memupuk dan meneruskan apa yang mereka perjuangkan lima tahun yang silam. Lambat laun, pada tahun 2003 dibentuklah team formatur yang notabene beranggotakan seluruh ketua-ketua Ikatan Keluarga Pelajar Mahahasiswa (IKPM) tiap Propinsi di Yogyakarta.

Sadar akan begitu pentingnya berorganisasi untuk mengejawantahkan semua gagasan-gagasan para IKPM-IKPM dalam satu wadah, pada tanggal 8 Februari 2004, IKPMDI-Yogyakarta secara resmi dideklarasikan di Balai Wanitatama Yogyakarta. Sejak 2004 tersebut bentuk kepengurusan menggunakan

\footnotetext{
${ }^{1}$ Ketua Umum Pusat Studi Mahasiswa Pascasarjana (PUSMAJA) Mbojo-Yogyakarta Periode 2015-2017 | | Ketua II Bagian Eksternal Dewan Pimpinan Cabang Perhimpunan Mahasiswa Hukum Indonesia Daerah Istimewa Yogyakarta (DPC PERMAHI DIY) Periode 2012-2014 | Email: jamilncera@gmail.com | FB/Youtube/IG/Twitter: @MJAMILSH | Website: http://www.mjamil.my.id.
} 
sistem Presidium. Lambat laun, pada Kongres ke-III di Gedung Dinas Sosial Yogyakarta tahun 2007, menghasilkan perubahan yang cukup signifikan dalam hal sistem dan tata kelola organisasi, sehingga berubah dari sistem Presidium menjadi sistem struktural seperti lembaga organisasi mahasiswa pada umumnya, yakni menggunakan Ketua Umum sebagai pucuk pimpinan organisasi.

Berawal dari tahun 2003 silam, IKPMDI-Yogyakarta sampai detik ini masih eksis menunjukkan taringnya dalam hal suksesi agenda-agenda positif yang mampu dinikmati oleh seluruh mahasiswa-mahsiswa yang berada di Yogyakarta. Dari agenda-agenda kebudayaan, sosial, dan agenda-agenda yang tidak kalah menarik lainnya mampu dihadirkan untuk membentuk karakter dan jati diri para mahasiswa-mahasiswa se-Nusantara yang ada di Yogyakarta. Sungguh, yang paling renyah dan selalu terngiang dalam pandangan Penulis adalah, saat ini IKPMDI-Yogyakarta konsisten mendidik mahasiswa-mahasiswa daerah untuk mau menyampaikan ide dan gagasannya seperti terkonsepkan secara rapi dalam bentuk Majalah Nusantara terbitan setiap dua bulan sekali.

Ibarat namanya, Majalah Nusantara diharapkan hadir untuk menampung ribuan gagasan para mahasiswa se-Nusantara di Yogyakarta yang telah menggumpal dalam benak pikiran para mahasiswa daerah.

Disadari atau tidak, sangat besar manfaatnya kalau kita menuliskan gagasan-gagasan yang telah tertanam dalam benak kita, jangan biarkan membeku, jangan hanya kita mengungkapkannya dengan lidah kepada orang lain, karena dengan cuman mengungkapkannya itu tidak akan berdampak luas penyebaran gagasan-gagasan tersebut. Oleh karena itu, sangat perlu kita menuliskannya sehingga gagasan-gagasan tersebut dapat menjangkau lebih luas melampaui apa yang kita bayangkan. Tidak tanggung-tanggung, bahkan gagasan tersebut mampu melampaui zaman. (bandingkan Tim Penulis PUSMAJA, 2017: vi).

Hadirnya Majalah Nusantara menjadi warna tersendiri dalam kancah dunia literasi di Indonesia, terlebih khusus lagi mampu menjadi jembatan emas untuk menampung gagasan-gagasan para kaum muda terdidik yang notabene kuliah di kota pendidikan (Yogyakarta). Majalah Nusantara menjadi satu-satunya wadah bersama untuk seluruh elemen mahasiswa IKPM-IKPM yang ada di Yogyakarta. 
Inilah yang disebut Penulis, "IKPMDI sebagai Wadah Pemersatu Gagasan Emas Para Mahasiswa Se-Nusantara" sebagai ide dan tema dasar tulisan ini. Karena lewat Majalah Nusantara, penulis-penulis lokal (mahasiswa daerah) mampu dengan leluasa mengekspresikan gagasan-gagasannya secara nyata dan dibaca semua elemen yang ada, terlebih elemen-elemen yang ada di lembaga IKPMIKPM se-Nusantara.

Terkadang, banyak juga penulis-penulis di antar IKPM-IKPM propinsi yang sepenuhnya belum tahu dan belum memahami kira-kira gagasan yang telah mereka sajikan dalam bentuk tulisan akan dituangkan di mana, dengan hadirnya Majalah Nusantara, menjawab kegelisahan tersebut. Terbukti hampir disemua edisi Majalah Nusantara mampu diwarnai oleh tulisan-tulisan beragam dari perwakilan-perwakilan IKPM propinsi se-Nusantara. Itulah kenikmatan tersendiri yang lahir dari hadirnya IKPMDI-Yogyakarta melalui Majalah Nusantara.

Satu dan lain hal, mudah rasanya kita ingin mengetahui potensi-potensi yang ada di daerah seluruh Indonesia, entah itu budayanya, adat istiadatnya, makanan-makanan khasnya, bahkan nilai-nilai luhur yang menjadi filosofis kehidupan tiap-tiap daerah. Karena dengan mengoleksi edisi-edisi yang telah diterbitkan IKPMDI-Yogyakarta melalui Majalah Nusantara, bisa kita dapatkan. Inilah yang perlu kita selalu lestarikan.

Setiap edisi yang diterbitkan Majalah Nusantara selalu renyah untuk dibaca, karena dalam tiap edisi selalu in dengan isu-isu yang sedang hangat diperbincangkan khalayak ramai.

Selain itu, bila dikontekskan dengan ke-Indonesia-an, isu-isu yang sedang berkembang banyak yang berpotensi menggerogoti keutuhan nilai-nilai dasar yang telah terkonsepkan dalam Pancasila. Beberapa diantaranya adalah penggorengan isu suku, agama, ras, antar golongan (SARA) dan radikalisme. Hadirnya IKPMDI-Yogyakarta juga mampu menjadi awal penangkal berkembangnya isu SARA dan radikalisme yang ada di Indonesia. Karena IKPMDI-Yogyakarta ibarat kata, merupakan miniaturnya lembaga negara. Tubuh kelembagaan IKPMDI-Yogyakarta terangkul semua perwakilan dari IKPM-IKPM Provinsi (31 provinsi) yang ada di Yogyakarta. Melalui perbincangan hangat dari 
"IKPMDI sebagai Wadah Pemersatu Gagasan Emas Para Mahasiswa Se-Nusantara"

IKPMDI-Yogyakarta bisa menjadi pintu awal penangkal isu-isu SARA dan radikalisme tersebut. Setelah diperbincangkang di lingkup IKPMDI-Yogyakarta, barulah perwakilan-perwakilan dari seluruh IKPM-IKPM Provinsi tersebut menyalurkan lagi dalam forum IKPM-IKPM Provinsi-nya masing masing. Kalau pun dalam kepengurusan IKPMDI-Yogyakarta belum secara utuh mengakomodir 31 IKPM provinsi, seperti biasanya dapat dikumpulkan dengan mudah seluruh ketua-ketua IKPM provinsi (atau perwakilan) dalam satu forum, dan mendiskusikannya secara bersama bagaimana dan seperti apa langkah-langkah kongkrit untuk menyelesaikan persoalan yang ada.

Dengan hadirnya edisi khususus "IKPMDI-Yogyakarta" ini, mampu secara gamblang kita mengetahui secara utuh dan menyeluruh, apa saja kiprah-kiprah yang telah dilakukan oleh IKPMDI-Yogyakarta dari awal mula berdiri sampai detik ini. Akhir kalimat, saya ucapkan selamat menikmati sajian-sajian tulisan renyah yang disuguhkan IKPMDI-Yogyakarta melalui Majalah Nusantara.

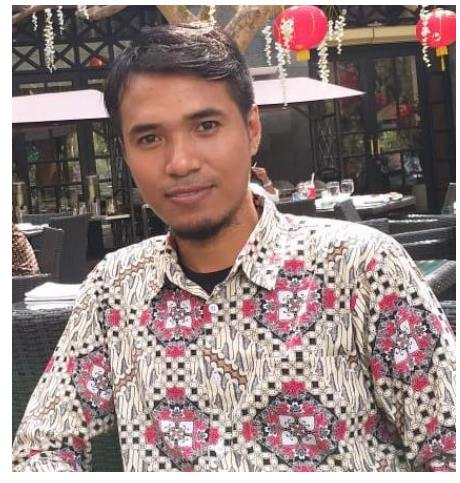

Penulis: M. Jamil, S.H.

Ketua Umum Pusat Studi Mahasiswa Pascasarjana (PUSMAJA) Mbojo-Yogyakarta Periode 2015-2017 | Ketua II Bagian Eksternal Dewan Pimpinan Cabang Perhimpunan Mahasiswa Hukum Indonesia Daerah Istimewa Yogyakarta (DPC PERMAHI DIY) Periode 2012-2014.

\section{Ful Sumber Tulisan:}

M. Jamil, "IKPMDI sebagai Wadah Pemersatu Gagasan Emas Para Mahasiswa Se-Nusantara", Majalah NUSANTARA IKPMDI-Yogyakarta, diterbitkan melalui Dinas Pendidikan Pemuda dan Olahraga (Disdikpora) Daerah Istimewa Yogyakarta, edisi November-Desember 2017. 